\title{
Assessment of the exposure pathway in the uptake and distribution of americium and cesium in cuttlefish (Sepia officinalis) at different stages of its life cycle
}

\author{
P. Bustamante $\underline{\underline{a}}$, J.-L. Teyssié ${ }^{\underline{\underline{b}}}$, S.W. Fowler $\underline{\underline{b}}, \underline{1}$ and M. Warnau $\underline{\underline{b}}$
}

\author{
aLaboratoire de Biologie et Environnement Marins, FRE 2727 du CNRS, Université de La Rochelle, 22, Avenue \\ Michel Crépeau, F-17042 La Rochelle, France \\ ${ }^{\mathrm{b}}$ Marine Environment Laboratory, International Atomic Energy Agency, 4 Quai Antoine Ier, MC-98000 Monaco
}

Corresponding author : pbustama@univ-Ir.fr

\begin{abstract}
:
Laboratory radiotracer experiments were performed to study the uptake, assimilation and retention of americium $\left({ }^{241} \mathrm{Am}\right)$ and cesium $\left({ }^{134} \mathrm{Cs}\right)$ by the common cuttlefish Sepia officinalis. Uptake and loss kinetics of the radionuclides were measured following exposure through sediments, seawater and food at different stages of the animal's life cycle. Sediment was found to be a minor uptake pathway for both radionuclides in juveniles. Following a short seawater exposure, cuttlefish accumulated ${ }^{241} \mathrm{Am}$ and ${ }^{134} \mathrm{Cs}$, but only to a limited extent (whole-body $\mathrm{CF}<2$ ). Among the cuttlefish organs, branchial hearts and their appendages displayed the highest degree of uptake for ${ }^{241} \mathrm{Am}$ (CF $=42$ and 16 , respectively), but these tissues contained low percentage of total ${ }^{241} \mathrm{Am}$ due to their relatively small contribution to whole organism weight. The major fraction of incorporated radionuclides was associated with muscular tissues (viz. $65 \%$ and $82 \%$ of total ${ }^{241} \mathrm{Am}$ and ${ }^{134} \mathrm{Cs}$, respectively). Wholebody loss of ${ }^{241} \mathrm{Am}$ and ${ }^{134} \mathrm{Cs}$ was relatively rapid $\left(T_{\mathrm{b} / 2}=14\right.$ and 6 days, respectively). After dietary exposure, around $60 \%$ and $30 \%$ of ingested ${ }^{241} \mathrm{Am}$ was assimilated into the tissues of juvenile and adult cuttlefish, respectively. However, assimilated ${ }^{241} \mathrm{Am}$ was more strongly retained in adults than in juveniles $\left(T_{\mathrm{b}^{1 / 2}}=28\right.$ vs. 5 days, respectively), suggesting that different mechanisms govern ${ }^{241} \mathrm{Am}$ elimination at both ages. Ingested ${ }^{134} \mathrm{Cs}$ was assimilated to a similar extent in juveniles (29\%) and adults $(23 \%)$, but the depuration rate was four times faster in adults. Our results strongly suggest that these two radionuclides follow different excretion pathways and that the mechanisms can vary with age for a given radionuclide.
\end{abstract}

Keywords: Accumulation; Biokinetics; Cephalopods; Radionuclides; Retention 
Assessment of exposure pathway to americium and cesium uptake and

2

4

$5 \quad$ P. Bustamante ${ }^{1 *}$, J-L. Teyssié ${ }^{2}$, S.W. Fowler ${ }^{2}, \&$ M. Warnau ${ }^{2}$

6

$7 \quad{ }^{1}$ Laboratoire de Biologie et Environnement Marins, FRE 2727 du CNRS, Université de La 8 Rochelle, 22, Avenue Michel Crépeau, F-17042 La Rochelle, France

9

$10{ }^{2}$ Marine Environment Laboratory - International Atomic Energy Agency, 4 Quai Antoine I ${ }^{\mathrm{er}}$, 11 MC-98000 Monaco

12

13 *Corresponding author. Tel.:+33 546500 294; e-mail: pbustama@ univ-lr.fr 
15 ABSTRACT: Laboratory radiotracer experiments were performed to study the uptake, assimilation and retention of americium $\left({ }^{241} \mathrm{Am}\right)$ and cesium $\left({ }^{134} \mathrm{Cs}\right)$ by the common cuttlefish

17 Sepia officinalis. Uptake and loss kinetics of the radionuclides were measured following 18 exposure through sediments, seawater and food at different stages of the animal's life cycle. 19 Sediment was found to be a minor uptake pathway for both radionuclides in juveniles. 20 Following a short seawater exposure, cuttlefish accumulated ${ }^{241} \mathrm{Am}$ and ${ }^{134} \mathrm{Cs}$, but only to 21 limited extent (whole-body $\mathrm{CF}<2$ ). Among the cuttlefish organs, branchial hearts and their 22 appendages displayed the highest degree of uptake for ${ }^{241} \mathrm{Am}(\mathrm{CF}=42$ and 16 , respectively), 23 but these tissues contained low percentage of total ${ }^{241} \mathrm{Am}$ due to their relatively small 24 contribution to whole organism weight. The major fraction of incorporated radionuclides was 25 associated with muscular tissues (viz. 65 and $82 \%$ of total ${ }^{241} \mathrm{Am}$ and ${ }^{134} \mathrm{Cs}$, respectively). 26 Whole-body loss of ${ }^{241} \mathrm{Am}$ and ${ }^{134} \mathrm{Cs}$ was relatively rapid $\left(\mathrm{Tb}_{1 / 2}=14\right.$ and $6 \mathrm{~d}$, respectively). 27 After dietary exposure, around $60 \%$ and $30 \%$ of ingested ${ }^{241} \mathrm{Am}$ was assimilated into the 28 tissues of juvenile and adult cuttlefish, respectively. However, assimilated ${ }^{241}$ Am was more 29 strongly retained in adults than in juveniles $\left(\mathrm{Tb}_{1 / 2}=28 v s 5 \mathrm{~d}\right.$, respectively), suggesting that 30 different metabolic processes govern ${ }^{241} \mathrm{Am}$ elimination at both ages. Ingested ${ }^{134} \mathrm{Cs}$ was 31 assimilated to a similar extent in juveniles (29\%) and adults (23\%), but the depuration rate 32 was 4 times slower in adults. Our results strongly suggest that these two radionuclides 33 followed different excretion pathways, and that the mechanisms can vary with age for a given 34 radionuclide.

Key words: Accumulation; Biokinetics; Cephalopods; Radionuclides; Retention 
39 Contamination of marine waters by radionuclides is a major concern in coastal areas, which 40 receive radioactive inputs from industries, accidents, and fallout from nuclear weapon testing. 41 Surveys estimating concentrations of chemicals in water or sediments are generally complemented by biomonitoring programs and marine mussels are often used as biological monitors for radionuclides and heavy metals (Goldberg 1975, Goldberg et al 1978, Goldberg et al 1983, Goldberg \& Bertine 2000). However, previous studies on the trophic transfer of trace elements and radionuclides have shown that herbivores (such as mussels) do not to any extent assimilate transuranic elements ingested with their food (e.g., Fowler 1982, Fisher et al. 1983, Warnau et al. 1996). Nevertheless this aspect has been little studied in higher trophic levels which are also used in many contaminant surveys. Therefore, there is a need to determine the bioaccumulation potential of marine carnivorous species for such elements. Previous investigations with cephalopods have shown that these carnivorous species do bioaccumulate radionuclides in their tissues that can at times reach high levels (Suzuki et al. 1978, Guary et al. 1981, Yamada et al. 1999); however, little information is available on the routes and rates of accumulation and retention of these radionuclides (Suzuki et al. 1978, Guary \& Fowler 1982). Two long-lived radionuclides, the particle-reactive ${ }^{241} \mathrm{Am}$ and the soluble ${ }^{134} \mathrm{Cs}$, are present in fallout and also commonly found in nuclear wastes. The objective of our study was to examine the biokinetics of uptake and loss of these two contrasting radionuclides in cephalopods in order to establish their bioaccumulation rates, tissue distribution and retention times depending on (1) the uptake pathway, and (2) the life stage of the organism. The common cuttlefish Sepia officinalis was selected as an experimental model,

60 and exposures to these two radionuclides via seawater, food and sediment were studied in 61 juvenile and adult individuals. 


\section{Experimental organisms}

66

67

Eggs of the common cuttlefish (Sepia officinalis L.) were obtained from cultured adults and were maintained in an aquarium with flowing seawater until hatching; the newly hatched juveniles $(\mathrm{n}=25 ; 0.387 \pm 0.071 \mathrm{~g}$ wet $\mathrm{wt})$ were then used in the experiments. Adult cuttlefish ( $\mathrm{n}=18 ; 138 \pm 40 \mathrm{~g}$ wet wt) were reared in the Monaco Oceanographic Museum from hatching to one year old organisms, or collected by net fishing off Monaco $(n=5 ; 253 \pm 97 \mathrm{~g}$ wet wt). All organisms were maintained in filtered seawater in constantly aerated open circuit aquaria (salinity: 36 p.s.u.; temperature: $16.5 \pm 0.5^{\circ} \mathrm{C} ; 12 / 12 \mathrm{~h}$ dark/light cycle).

Prior to experimentation, adults were anaesthetised in $2 \%$ ethanol in seawater for making biometric measurements, sex determination and for the insertion of a numbered plastic tag into the mantle fin to identify each animal during the experiments.

\section{Radionuclides}

${ }^{241} \mathrm{Am}\left[\mathrm{t}_{1 / 2}=433 \mathrm{yr}\right]$ and ${ }^{134} \mathrm{Cs}\left[\mathrm{t}_{1 / 2}=2 \mathrm{yr}\right]$ purchased from Amersham, UK, as nitrate and chloride salts, respectively, were used to trace americium ad cesium biokinetics. Stock solutions were prepared in their respective solutions $(0.1 \mathrm{~N})$ to obtain radioactivities which would allow using spikes of only a few microliters (typically 10 to $20 \mu \mathrm{L}$ ).

\section{${ }^{241} \mathrm{Am}$ and ${ }^{134} \mathrm{Cs}$ uptake via sediments}

Sediments (2.5 kg dry wt) from the North Sea (Audresselles, Pas-de-Calais, France) were spiked for $4 \mathrm{~d}$ with ${ }^{241} \mathrm{Am}$ and ${ }^{134} \mathrm{Cs}$ using the rolling jar method (Murdoch et al. 1997). Before initiating the experiment, radiolabelled sediments were held in flowing seawater overnight in order to leach weakly bound radiotracer. Sediments $(50 \mathrm{~g}$ wet wt) were sampled at fixed intervals during the experiment to check for possible variations in radionuclide 
concentration. Juvenile cuttlefish $(n=9)$ were exposed for 29 d in a $20-\mathrm{L}$ plastic aquarium

90

91

92

containing ca. $3 \mathrm{~L}$ of natural seawater running over a $4 \mathrm{~cm}$ layer of spiked sediment. The level of sea water was maintained low in order to minimise the movements required for feeding and to maximise the contact time with sediments. During the experiment, all juvenile cuttlefish were fed twice daily with brine shrimp Artemia salina and were periodically $\gamma$-counted to follow the radionuclide uptake kinetics over the $29 \mathrm{~d}$. At the end of the uptake experiment, 3 individuals were dissected to determine the distribution of the radionuclides among digestive gland, cuttlebone and remaining tissues (including other organs).

\section{${ }^{241} \mathrm{Am}$ and ${ }^{134} \mathrm{Cs}$ uptake via seawater and subsequent loss}

Newborn $(n=8)$ and adult $(n=5)$ cuttlefish were placed for $36 \mathrm{~h}$ and $8 \mathrm{~h}$, respectively, in 70 L glass aquaria containing seawater spiked with ${ }^{241} \mathrm{Am}$ and ${ }^{134} \mathrm{Cs}$ (nominal activity: $6 \mathrm{kBq} \mathrm{L} \mathrm{L}^{-1}$ each). Cuttlefish were then radioanalyzed and transferred to another 70-L aquarium supplied with natural flowing seawater. Juvenile cuttlefish were fed A. salina twice daily and were periodically $\gamma$-counted to follow radionuclide loss kinetics over $29 \mathrm{~d}$. At the end of the loss period, 4 juveniles were dissected to determine the radionuclide distribution among digestive gland, cuttlebone and remaining tissues.

During the loss phase, adults were fed daily with soft parts of the mussel Mytilus galloprovincialis. Three adults were dissected after $8 \mathrm{~h}$ and the remaining two were dissected after $6 \mathrm{~d}$ of depuration. For each individual, the branchial heart appendages, branchial hearts, gills, digestive tract (after removal of the gut contents), genital tract, ovary or testes, ink sack, digestive gland, kidneys, mantle skin, mantle muscle, head and cuttlebone were separated, weighed, and their radionuclide content measured.

\section{${ }^{241} \mathrm{Am}$ and ${ }^{134} \mathrm{Cs}$ accumulation from food}


114 To prepare radiolabelled food, mussels (M. galloprovincialis) and brine shrimp (A. salina)

115 were exposed for $7 \mathrm{~d}$ in plastic aquaria containing $4 \mathrm{~L}$ of natural seawater spiked with ${ }^{241} \mathrm{Am}$

116 and ${ }^{134} \mathrm{Cs}$ (nominal activity: $6 \mathrm{kBq} \mathrm{L} \mathrm{L}^{-1}$ each). Radiolabelled seawater was renewed daily and

117 the organisms were subsequent ly used as food for newborn (brine shrimp) and adult (mussels)

118 cuttlefish.

119 For identification purposes, each individual juvenile cuttlefish $(n=8)$ was enclosed in a

120 separate compartment allowing free circulation of seawater in a 70-L aquarium. After $1 \mathrm{~h}$ of

121 ingesting radiolabelled brine shrimp, each individual was immediately $\gamma$-counted. From that

122 time on cuttlefish were fed twice daily with non-contaminated A. salina, and regularly $\gamma$ -

123 counted to determine radiotracer loss kinetics and assimilation efficiency. Throughout the

124 depuration period ( 29 d), feces were removed 3 times per day to reduce possible indirect

125 contamination by radiotracer recycling through leaching from the Eces. At the end of the

126 depuration period, 5 juveniles were dissected to determine the radiotracer distribution in their

127 tissues.

128 Adult cuttlefish $(\mathrm{n}=18)$ were held in a $3000 \mathrm{~L}$ aquarium and fed soft parts of the previously

129 labelled mussels for $2 \mathrm{~h}$. Immediately after ingestion, each individual was $\gamma$-counted and the

130 same procedure was followed as for the juveniles. In addition, 3 adult cuttlefish were

131 dissected at each counting time to determine the radiotracer distribution among their organs

132 and tissues.

133

134 Radioanalyses.

135 Radioactivity was measured using a high-resolution $\gamma$-spectrometry system consisting of three

136 coaxial Ge (N- or P-type) detectors (EGNC 33-195-R, Intertechnique) connected to a

137 multichannel analyser and a computer with spectra analysis software (Interwinner,

138 Intertechnique). The detectors were calibrated with appropriate standards for each of the

139 counting geometries used, and measurements were corrected for background and physical 
decay of the radionuclides. Counting times were adapted to obtain relative propagated errors

141 less than 5\%. However, in a few cases, this counting precision could not be obtained even

142 after $48 \mathrm{~h}$ of counting due to the very low activity in extremely small organs. Counting times

143 ranged from $10 \mathrm{~min}$ to $1 \mathrm{~h}$ for whole cuttlefish, mussels and brine shrimp, and from $10 \mathrm{~min}$ to

$14448 \mathrm{~h}$ for the dissected organs and tissues.

145

146 Data and statistical analyses.

147 Uptake of ${ }^{241} \mathrm{Am}$ and ${ }^{134} \mathrm{Cs}$ from sediments and seawater was expressed, respectively, as 148 whole-body transfer factors (TF) and concentration factors (CF) over time $\left(\mathrm{Bq} \mathrm{g}^{-1}\right.$ wet wt 149 organism divided by the time-integrated $\mathrm{Bq} \mathrm{g}^{-1}$ in sediments $-\mathrm{TF}-$ or seawater $-\mathrm{CF}-$ ).

150 Radionuclide loss was expressed in terms of percentage of remaining radioactivity over time,

151 i.e. radioactivity at time $t$ divided by initial radioactivity measured in the organisms at the

152 beginning of the depuration period. Loss kinetics were described either by a single-component

153 exponential model:

$$
A_{t}=A_{0} e^{-k t}
$$

where $A_{t}$ and $A_{0}$ are remaining activities (\%) at time $t(\mathrm{~d})$ and 0 , respectively, or by a 2 component exponential model:

$$
A_{t}=A_{0 s} e^{-k_{s} t}+A_{0 l} e^{-k_{l} t}
$$

158 where the 's' subscript refers to a short-lived component (s component) and the 'l' subscript

159 refers to a long-lived component (1 component) (Whicker \& Schultz 1982, Warnau et al.

160 1996). The exponential model showing the best fit (based on calculation of the determination

161 coefficients, $\mathrm{R}^{2}$, and examination of the residuals) was selected.

162 Parameter $\mathrm{k}$ allows the calculation of the radionuclide biological half-life (d) using the 163 following equation:

$$
\mathrm{T}_{\mathrm{b}^{1 / 2}}=\ln 2 / \mathrm{k} \text {. }
$$


Constants of the models and their statistics were estimated by iterative adjustment of the

166

167

168

169

170

171

172

173

174

175

176

177

178

179

180

181

182

183

184

185

186

187

188

189

model and Hessian matrix computation, respectively, using the non-linear curve-fitting routines in the Systat 5.2.1 Software (Wilkinson 1988). Changes in radionuclide distribution among cuttlefish tissues and organs were tested for significance by the G procedure (adapted from the log-likelihood ratio test) for 2xk contingency tables (Zar 1996). Changes in \% of radioactivity in a single tissue during the depuration period were tested by one-way ANOVA (after arcsin transformation of data) followed by the HSD Tukey's multiple comparison test. The significance level for statistical analyses was always set at $\alpha=0.05$.

(1)

RESULTS

(1)

\section{Sediment exposure}

Regular measurements of ${ }^{241} \mathrm{Am}$ concentration in sediment did not show any significant variation during the experimental time course $\left(14.5 \pm 1.8 \mathrm{~Bq} \mathrm{~g}^{-1}\right.$ wet wt $)$ while ${ }^{134} \mathrm{Cs}$ activities decreased from $12.4 \pm 0.1$ to $7.0 \pm 0.4 \mathrm{~Bq} \mathrm{~g}^{-1}$ wet wt.

Very low ${ }^{241} \mathrm{Am}$ and ${ }^{134} \mathrm{Cs}$ activities were recorded in juveniles cuttlefish even after $29 \mathrm{~d}$ of exposure, and transfer factors (TF) were lower than 0.5 for both elements. Dissection of 3 individuals after $29 \mathrm{~d}$ of exposure showed that, for both nuclides, the digestive gland contained the highest proportion of the whole-body burden, i.e. $47 \pm 28 \%$ of ${ }^{241} \mathrm{Am}$ and $49 \pm$ $12 \%$ of ${ }^{134} \mathrm{Cs}$ (Table 1$)$.

\section{Seawater exposure}

Regular monitoring of the radionuclide concentrations in seawater allowed calculation of time-integrated radioactivities, viz. $6.4 \pm 0.3$ and $8.6 \pm 0.7 \mathrm{kBq} \mathrm{L}{ }^{-1}$ for ${ }^{241 \mathrm{~m}} \mathrm{Am}$ and ${ }^{134} \mathrm{Cs}$, respectively. 
Juveniles. The whole-body activities measured after $36 \mathrm{~h}$ of exposure in spiked seawater were $38 \pm 10$ and $37 \pm 1 \mathrm{~Bq} \mathrm{~g}^{-1}$ wet wt for ${ }^{241} \mathrm{Am}$ and ${ }^{134} \mathrm{Cs}$, respectively, giving relatively low

192 mean calculated whole-body CFs of $6 \pm 2$ and $4 \pm 1$ for these radionuclides.

193 Following transfer to non-contaminated seawater, loss kinetics of ${ }^{241} \mathrm{Am}$ in juvenile cuttlefish

194 were best fitted by a single-component exponential model whereas loss of ${ }^{134} \mathrm{Cs}$ was best 195 described by a two-component model (Figs 1A and 1B; Table 2). Loss kinetics were 196 characterised by a biological half- life $\left(\mathrm{T}_{\mathrm{b}^{1 / 2}}\right)$ of $2 \mathrm{wk}$ for ${ }^{241} \mathrm{Am}$ and $1 \mathrm{wk}$ for ${ }^{134} \mathrm{Cs}$.

197 At the end of the depuration period, ${ }^{134} \mathrm{Cs}$ was mainly associated with the digestive gland of 198 the young cuttlefish ( $61 \pm 4 \%$ of whole-body activity) whereas ${ }^{241}$ Am was mainly retained in 199 the remaining tissues $(61 \pm 13 \%)$ (Table 1$)$. The lowest fraction of both radiotracers was 200 found in the cuttlebone ( $<15 \%$ of the total activity).

201 Adults. ${ }^{241} \mathrm{Am}$ and ${ }^{134} \mathrm{Cs}$ activities recorded in whole-body as well as in the different organs 202 and tissues of adult cuttlefish after $8 \mathrm{~h}$ of exposure and corresponding CFs are presented in 203 Table 3. The highest activities of ${ }^{241} \mathrm{Am}$ were found in the branchial hearts and their 204 appendages $\left(264 \pm 85\right.$ and $103 \pm 66 \mathrm{~Bq} \mathrm{~g}^{-1}$ wet wt, respectively). In the case of ${ }^{134} \mathrm{Cs}$, the 205 branchial hearts, their appendages, the gills and the digestive tract displayed the highest activities, ranging from 9 to $13 \mathrm{~Bq} \mathrm{~g}^{-1}$ wet wt.

207 When considering the tissue distribution of the radionuclides, muscle and skin of adults (i.e. 208 the sum of the mantle muscles, skin and head) contained the highest proportion of ${ }^{241} \mathrm{Am}$ and $209{ }^{134} \mathrm{Cs}$, viz. 68 and $85 \%$, respectively (Table 3). A somewhat lesser ${ }^{241}$ Am fraction was found 210 in the branchial hearts and digestive gland (10 $\pm 2 \%$ for both tissues). The radionuclide 211 distribution among the tissues did not vary significantly $(G$ test, $p>0.05)$ between the 212 beginning and the end of the depuration period (Table 3). 
215 In these experiments, juveniles $(\mathrm{n}=8)$ were fed radiolabelled adult brine shrimp ad libitum 216 for $1 \mathrm{~h}$ and adult cuttlefish $(\mathrm{n}=18)$ ingested a total of 123 radiolabelled mussels during a 2-h 217 feeding. Immediately after feeding, all cuttlefish were $\gamma$-counted for determination of their 218 radionuclide content.

219 Juveniles. The loss kinetics of ingested ${ }^{241} \mathrm{Am}$ and ${ }^{134} \mathrm{Cs}$ were best fitted by a 2-component 220 exponential model composed of one rapid loss component followed by one slow component 221 (Figs 1C and 1D; Table 2). The short-lived component was derived from $40 \%$ and $70 \%$ of the 222 initially ingested ${ }^{241} \mathrm{Am}$ and ${ }^{134} \mathrm{Cs}$ activities, respectively (Table 2) and was characterised by a $223 \mathrm{~T}_{\mathrm{b}^{1 / 2 \mathrm{~s}}}<1 \mathrm{~d}$ for both radionuclides. The long-lived component, which represents the fraction of 224 the radionuclides actually absorbed by cuttlefish, displayed a $\mathrm{T}_{\mathrm{b}^{1 / 2}}$ of $5 \mathrm{~d}$ for ${ }^{241} \mathrm{Am}$ and $66 \mathrm{~d}$ 225 for ${ }^{134} \mathrm{Cs}$ (Table 2). The same long-lived component allowed estimation of the assimilation 226 efficiencies (AE) of the ingested nuclides. Results showed that ${ }^{241}$ Am was readily assimilated 227 in juveniles with $\mathrm{AE}$ of $60 \%$ whereas the $\mathrm{AE}$ of ${ }^{134} \mathrm{Cs}$ was much lower, viz. 29\% (Table 2). 228 Dissections performed $29 \mathrm{~d}$ after feeding indicated that the highest proportion of remaining 229 activity of both nuclides occurred in the digestive gland (ca. 60\% of the whole-body activity; 230 Table 1).

231 Adults. The loss kinetics of both radionuclides ingested with food by adult cuttlefish were 232 best described by a 2-component exponential model. As shown Figs 1E and 1F and in Table 2332,69 and $78 \%$ of the ingested activity of ${ }^{241} \mathrm{Am}$ and ${ }^{134} \mathrm{Cs}$, respectively, were rapidly lost with $234 \mathrm{a} \mathrm{T}_{\mathrm{b}^{1 / 2 \mathrm{~S}}}$ of 4 and $13 \mathrm{~h}$, respectively. The assimilated fraction of ingested ${ }^{241} \mathrm{Am}$ was much lower 235 in adults than in juveniles $(\mathrm{AE}=31$ vs $60 \%)$ but was lost at a slower rate with a $\mathrm{T}_{\mathrm{b} / 21}$ of $28 \mathrm{~d}$ 236 compared to $5 \mathrm{~d}$ in juveniles. For ${ }^{134} \mathrm{Cs}$, AEs were nearly similar at both ages $(\mathrm{AE}=23 \mathrm{vs}$ $23729 \%$ in adults and juveniles, respectively) but the radionuclide was lost much faster in adults 238 $\left(T_{b^{1} / 2 l}=16 d\right)$ than in juveniles $\left(T_{b^{1} / 2 l}=66 d\right)$. 
The tissue distribution of ingested radionuclides was determined on several occasions after

240 feeding (Table 4). At the end of the depuration period, both ${ }^{241} \mathrm{Am}$ and ${ }^{134} \mathrm{Cs}$ were 241 predominantly distributed in the digestive gland (viz. 98 and 54\%, respectively). The 242 distribution of ${ }^{241} \mathrm{Am}$ among tissues remained unchanged for $29 \mathrm{~d}$ of observation; in contrast, 243 some significant changes were observed for ${ }^{134} \mathrm{Cs}(\mathrm{G}$-test, $\mathrm{p}=0.01)$. For example, the 244 proportion of ${ }^{134} \mathrm{Cs}$ activity decreased in the muscular tissues (mantle muscles and head) 245 whereas between 1 and 18 days of excretion it increased in the digestive gland (Table 4).

\section{DISCUSSION}

Cephalopods are an important resource of marine food and are fished and consumed in large quantities all around the world (Amaratunga 1983). The intake of contaminants such as radionuclides by humans through cephalopod consumption is therefore a matter of potential concern. Cephalopods have been reported to concentrate natural and anthropogenic radionuclides such as ${ }^{210} \mathrm{Po},{ }^{210} \mathrm{~Pb},{ }^{137} \mathrm{Cs}$, and ${ }^{239+240} \mathrm{Pu}$ in their tissues (e.g. Smith et al. 1984, Finger \& Smith 1987, Yamada et al. 1999); however, little is known about the metabolism of radionuclides in these higher trophic level molluscs. To the best of our knowledge, only two species of cephalopods, viz. the octopus Octopus vulgaris and the squid Doryteuthis bleerkeri have been investigated experimentally for Am, Cs, and Pu (Suzuki et al. 1978, Guary \& 258 Fowler 1982). These works were limited to seawater uptake (i.e. Suzuki et al. 1978) or used a 259 less than optimal experimental approach such as injecting the prey with radionuclides for the 260 feeding experiments (Guary \& Fowler 1982).

261 Overall, cephalopods are found in a great variety of habitats from coastal waters to very deep 262 ocean environments, some live in direct contact with bottom sediments, and others experience 263 different environments during their life cycle (e.g. demersal species becoming temporarily 264 pelagic during migration). Therefore, there is a further need to determine 1) the uptake and 
retention of radionuclides at different stages of the life cycle of cephalopods, and 2) to assess

266 the relative importance of the different pathways of exposure to radionuclides (sediments, 267 seawater and food). In this context, the common cuttlefish Sepia officinalis appeared to be a 268 good model for such experiments as it spends part of its time buried in the sediment and is 269 easy to rear under laboratory conditions.

270

271 After 1 month of exposure to ${ }^{241} \mathrm{Am}$ and ${ }^{134} \mathrm{Cs}$ through sediments, juvenile cuttlefish still 272 exhibited very low transfer factors $(\mathrm{TF}<0.5)$, indicating that direct contamination due to 273 burying into sediments is a minor uptake pathway for these radionuclides in cephalopods. The 274 occurrence of a substantial fraction of both nuclides in internal tissues (viz. digestive gland 275 and cuttlebone), which have no direct contact with the sediment suggests that both 276 radionuclides were progressively translocated from the tissues in direct contact with sediment 277 to the digestive gland and, to a lesser extent, to the cuttlebone (see Table 1). Such a 278 translocation to the cuttlebone was observed in a previous study on bioaccumulation of $\mathrm{Cd}$ in 279 S. officinalis (Bustamante et al. 2002).

280 Following a short contamination of adults via seawater, activities recorded in the whole 281 cuttlefish suggest that they do not efficiently accumulate ${ }^{241} \mathrm{Am}$ and ${ }^{134} \mathrm{Cs}$ directly from the 282 dissolved phase. Indeed, both elements displayed low whole-body CFs (CF $=2$ for ${ }^{241} \mathrm{Am}$ and $283 \mathrm{CF}=1$ for ${ }^{134} \mathrm{Cs}$ ). Activities of ${ }^{134} \mathrm{Cs}$ measured in the different organs and tissues were all of 284 the same order of magnitude. In contrast, for ${ }^{241} \mathrm{Am}$ the organs involved in respiration (the 285 branchial hearts, their appendages and the gills) and digestion (digestive gland) displayed 286 higher activities compared to others body compartments (see Table 3). However, in terms of 287 their relative distribution in the whole body, both radionuclides were mainly found in 288 muscular tissues which represent the main fraction (viz. 75\%) of the total body weight: 289 muscles and head contained $65 \%$ and $82 \%$ of the total ${ }^{241} \mathrm{Am}$ and ${ }^{134} \mathrm{Cs}$, respectively. A longer 290 exposure (14 d) of octopus Octopus vulgaris to ${ }^{137} \mathrm{Cs}$ in water gave a similar distribution (i.e. 
$88 \%$ ) of the radioisotope in the edible parts (Suzuki et al. 1978). In contrast, a 15-d exposure

292 of the same species in seawater spiked with ${ }^{241} \mathrm{Am}$ resulted in only ca. $20 \%$ of the retained 293 radioactivity being found into the muscular parts with ${ }^{241} \mathrm{Am}$ mainly being concentrated in the 294 branchial hearts and their appendages (Guary \& Fowler 1982). In our experiments with $S$. 295 officinalis, these tissues contained low percentages of the total ${ }^{241} \mathrm{Am}$, most probably because of the short duration of the experiment. Nevertheless, they significantly concentrated the

\section{7}

314 In the case of dietary exposure, $31 \pm 3 \%$ of the ingested ${ }^{241} \mathrm{Am}$ was assimilated into the tissues 315 of adult cuttlefish, whereas, in contrast, ${ }^{241} \mathrm{Am}$ was absorbed to a much greater extent in 316 radionuclide with $\mathrm{CF}$ reaching 42 in the branchial hearts and 16 in the appendages.

Both field and laboratory investigations on cephalopods have demonstrated the ability of branchial hearts to concentrate transuranic elements to fairly high levels (Guary et al. 1981, Guary \& Fowler 1982). This ability could be related to the presence of polyhedral cells containing granular, Fe-rich, pigment concretions (adenochromes) (e.g., Fox \& Updegraff 1943, Nardi \& Steinberg 1974). The affinity of ${ }^{241}$ Am for adenochromes in the branchial hearts has been demonstrated using autoradioradiographic techniques (Miramand \& Guary 1981); however, adenochromes have not been found in the appendages of the branchial hearts (Nardi \& Steinberg 1974), an observation which suggests that they serve as an excretion pathway for ${ }^{241} \mathrm{Am}$ rather than as storage sites.

Following exposure of juveniles in contaminated seawater, subsequent ${ }^{241} \mathrm{Am}$ and ${ }^{134} \mathrm{Cs}$ elimination over a one month period followed a one- and a two-component exponential loss model, respectively. Whole-body loss was relatively rapid for both nuclides, with mean $T_{b 1 / 2}$ of 14 and $6 \mathrm{~d}$, respectively. After $29 \mathrm{~d}$ of depuration, residual ${ }^{241}$ Am was mainly located in the remaining tissues (comprising the branchial hearts) of juveniles. However, as the juvenile branchial hearts were not fully developed, additional work is needed to examine their role as preferential storage organs as occurs in adults. juveniles $(\mathrm{AE}=60 \pm 10 \%)$. This difference between AEs could be due to difference in 
efficiency of digestion between juveniles and adults, since digestive metabolism is thought to

318 decrease with age in cephalopods (Mangold 1989). More likely, however, the difference could 319 also be due partly to variations in the bioavailability of ${ }^{241} \mathrm{Am}$ in the food used for juveniles 320 (brine shrimp) compared to that used for adults (mussels). Indeed, different storage 321 mechanisms in prey can determine metal bioavailability to higher trophic levels (Wallace \& Lopez 1997), which can lead to different proportions of transferable ${ }^{241}$ Am. Overall, such very high $\mathrm{AEs}$ for ${ }^{241} \mathrm{Am}$ in the common cuttlefish are rather unique whereas in herbivorous

324 bivalves, many crustaceans, echinoids, and fish assimilation of particle-reactive transuranic 325 elements is typically very low (e.g. Fowler et al., 1976; Penthreat 1977, 1981; Fisher et al., 326 1983; Carvalho and Fowler, 1985; Warnau et al., 1996). Such a difference could be related to the feeding regime as cephalopods are strict carnivores. For instance, unexpected high AEs (up to $60 \%$ ) of plutonium have also been found in carnivorous crustaceans, viz. the crabs Carcinus maenas and Cancer pagurus (Fowler and Guary, 1977). Hence, the contribution of 330 the trophic pathway is very likely to be strongly enhanced in certain carnivorous 331 invertebrates.

332 Once assimilated, ${ }^{241} \mathrm{Am}$ was retained to a much greater degree in adults, with a half-life 6 333 times longer than in juveniles (i.e. $28 \mathrm{~d} v s 5 \mathrm{~d}$ ), which suggests that different processes govern $334{ }^{241}$ Am elimination/retention at the two life stages. In other molluscs such as mussels, ${ }^{241} \mathrm{Am}$ 335 has been reported to be strongly retained in the digestive gland (Bjerregaard et al. 1985, 336 Fisher \& Teyssié 1986), a finding which is in agreement with our own observations. Indeed, 337 after $29 \mathrm{~d}$ of depuration, the major fraction of residual ${ }^{241} \mathrm{Am}$ was in the digestive gland, with 338 a much higher fraction was in adults than in juvenile cuttlefish (98\% vs 59\%). In the digestive 339 gland of the octopus O. vulgaris, Guary \& Fowler (1982) reported that ${ }^{241} \mathrm{Am}$ is likely 340 associated with the cellular waste products such as brown bodies. Considering this hypothesis 341 together with our experimental observations, the longer retention of ${ }^{241} \mathrm{Am}$ observed in adult 
342 S. officinalis could be due to a more rapid turnover of digestive cells in juveniles, thus leading 343 to a higher ${ }^{241}$ Am excretion rate.

344 In contrast to ${ }^{241} \mathrm{Am}$, ingested ${ }^{134} \mathrm{Cs}$ was assimilated to a similar extent in juveniles (29\%) and 345 adults (23\%) and depuration rate constant was 4 times higher in adults, resulting in a 346 significantly much shorter ${ }^{241}$ Am half- life in adults (16 d) than in juveniles (66 d) (Table 2).

347 The longer retention time of ${ }^{134} \mathrm{Cs}$ in juveniles is difficult to explain since, for certain 348 transition elements ( $\mathrm{Ag}, \mathrm{Cd}, \mathrm{Co}$ and $\mathrm{Zn}$ ) previously investigated in cuttlefish (Bustamante et 349 al. 2002, 2004) as well for ${ }^{241} \mathrm{Am}$ (our study), early juveniles displayed shorter retention times 350 than adults. The main difference in tissue distribution of ${ }^{134} \mathrm{Cs}$ between adults and juveniles 351 was the higher proportion present in the cuttlebone $(22 \pm 21 \%$ in juveniles $v s 2 \pm 0 \%$ in 352 adults; see Tables 1 and 4). This higher skeleton-associated fraction is most likely tightly 353 bound and hence results in the high retention time observed. Although, our results clearly 354 indicate that ${ }^{134} \mathrm{Cs}$ would not follow the same excretion pathway as ${ }^{241} \mathrm{Am}$, the above 355 interpretation should be considered with caution since to the best of our knowledge, 356 calcareous skeletons are not documented to act as a particularly efficient sink for cesium in 357 contrast with other elements such as e.g. ${ }^{241} \mathrm{Am}$ or $\mathrm{Pb}$ (see e.g. Grillo et al. 1981, Warnau et al. 1998). Furthermore, in this feeding experiment the very low activities measured in minute organs such as juvenile cuttlebone were frequently associated with low counting accuracy,

360 which in turn can lead to a rather poor estimation of radioactivities and hence radionuclide 361 distribution (as indicated by the elevated SD value of the cuttlebone-associated fraction of $\left.362{ }^{134} \mathrm{Cs}\right)$. Clearly, further study is needed to better understand the differences observed in the 363 fate of ${ }^{134} \mathrm{Cs}$ and ${ }^{241} \mathrm{Am}$ once taken up in young and adult cephalopod tissues.

365 Acknowledgements. We thank N. Tevenin and P. Gilles (Musée Océanographique, Monaco)

366 for providing us with the organisms. We are also grateful to E. Boucaud-Camou (Université 367 de Caen, France) for her advice on cuttlefish rearing. MW is an Honorary Research Associate 
of the National Fund for Scientific Research (NFSR, Belgium). The Marine Environment

369

370

371

372

373

374

375

376

377

378

379

380

381

382

383

384

385

386

387

388

389

390

391

392

393

394

395

396

397

398

399

Laboratory operates under a bipartite agreement between the International Atomic Energy Agency and the Government of the Principality of Monaco.

\section{LITERATURE CITED}

Amaratunga, T., 1983. The role of cephalopods in the marine ecosystem. In: IF Caddy (ed.). Advances in assessment of world cephalopod resources. FAO Fish Tech Pap 231:379-415

Bjerregaard, P., Topçuoglu, S., Fisher, N.S., Fowler, S.W., 1985. Biokinetics of americium and plutonium in the mussel Mytilus edulis. Mar Ecol Prog Ser 21:99-111

Bustamante, P., Teyssié, J-L., Fowler, S.W., Cotret, O., Danis, B., Miramand, P., Warnau, M., 2002. Biokinetics of zinc and cadmium accumulation and depuration at different stages in the life cycle of the cuttlefish Sepia officinalis. Mar Ecol Prog Ser 231:167-177

Bustamante, P., Teyssié, J-L., Danis, B., Fowler, S.W., Miramand, P., Cotret, O., Warnau, M., 2004. Uptake, transfer and distribution of silver and cobalt in tissues of the common cuttlefish Sepia officinalis at different stages of its life cycle. Mar Ecol Prog Ser 269:185-195

Carvalho, F.P., Fowler, S.W., 1985. Biokinetics of plutonium, americium and californium in the marine isopod Cirolana borealis, with observations on its feeding and molting behavior. Mar Biol 89:173-181

Finger, J.M., Smith, J.D., 1987. Molecular association of $\mathrm{Cu}, \mathrm{Zn}, \mathrm{Cd}$ and ${ }^{210} \mathrm{Po}$ in the digestive gland of the squid Nototodarus gouldi. Mar Biol 95:87-91

Fisher, N.S., Bjerregaard, P., Fowler, S.W., 1983. Interaction of marine plankton with transuranic elements. 3. Biokinetics of neptunium, plutonium, americium, and californium in phytoplankton. Limnol Oceanogr 28:432-447 
400 Fisher, N.S., Teyssié, J-L., 1986. Influence of food composition on the biokinetics and tissue

401 distribution of zinc and americium in mussels. Mar Ecol Prog Ser 28:197-207

402

403 Fowler, S.W., 1982. Biological transfer and transport processes. In: Kullenberg G (ed.)

404 Pollutant transfer and transport in the sea, Vol. 2. CRC Press, Boca Raton, Florida

405

406 Fowler, S.W., Guary, J-C., 1977. High absorption efficiency for ingested plutonium in crabs.

407 Nature 266, 827-828

408

409 Fowler, S.W., Heyraud, M., Cherry, R.D., 1976. Accumulation and retention of plutonium by

410 marine zooplankton. In: Activities of the International Laboratory of Marine Radioactivity, 4111976 Report. International Atomic Energy Agency, Vienna, Austria, pp. 42-50

412

413 Fox, D.L., Updegraff, D.M., 1943. Adenochrome a glandular pigment in the branchial hearts 414 of the octopus. Archs Biochem 1:339-356

415

416 Goldberg, E.D. 1975. The mussel watch - A first step in global marine monitoring. Mar 417 Pollut Bull 6:111

419 Goldberg, E.D., Bowen, V.T., Farrington, J.W., Harvey, G., Martin, J.H., Parker, P.L., 420 Risebrough, R.W., Robertson, W., Schneider, E., Gamble, E., 1978. The Mussel Watch. 421 Environ Conserv 5:101-125

422

423 Goldberg, E.D., Koide, M., Hodge, V., Flegal, A.R., Martin, J.H., 1983. U.S. Mussel 424 Watch:1977-1978 results on trace metals and radionuclides. Estuarine Coast Shelf Sci 16:69$425 \quad 93$

426

427 Goldberg, E.D., Bertine, K.K., 2000. Beyond the Mussel Watch- New direction for 428 monitoring marine pollution. Sci Total Environ 247:165-174

429

430 Grillo, M.C., Guary, J-C., Fowler, S.W., 1981. Comparative studies on transuranium nuclide 431 biokinetics in sediment-dwelling invertebrates. In: Impacts of Radionuclide Releases into the 432 Marine Environment. IAEA Publ., Vienna, pp. 273-291

433 
434 Guary, J-C., Higgo, J.J.W., Cherry, R.D., Heyraud, M., 1981. High concentrations of

435 transuranic and natural radioactive elements in the branchial hearts of the cephalopods

436 Octopus vulgaris. Mar Ecol Prog Ser 4:123-126

437

438 Guary, J-C., Fowler, S.W., 1982. Experimental studies on the biokinetics of plutonium and 439 americium in the cephalopod Octopus vulgaris. Mar Ecol Prog Ser 7:327-335

Mangold, K., 1989. Reproduction, croissance et durée de vie. In: Grassé PP (ed) Traité de 442 zoologie, Tome V. Céphalopodes. Masson, Paris

Miramand, P., Guary, J-C., 1981. Association of americium-241 with adenochromes in the branchial hearts of the cephalopod Octopus vulgaris. Mar Ecol Prog Ser 4:127-129

Murdoch, M.H., Chapman, P.M., Norman, D.M., Quintino, V.M., 1997. Spiking sediment

Nardi, G., Steinberg, H., 1974. Isolation and distribution of adenochrome(s) in Octopus vulgaris. Comp Biochem Physiol 48 B:453-461

452

Penthreath R.J., 1977. Radionuclides in marine fish. Oceanographic Marine Biology Annual

Penthreath R.J., 1977. The biological availability to marine organisms of transuranic and other long-lived radionuclides. p241-272

Smith, J.D., Plues, L., Heyraud, M., Cherry, R.D., 1984. Concentrations of the elements Ag, $\mathrm{Al}, \mathrm{Ca}, \mathrm{Cd}, \mathrm{Cu}, \mathrm{Fe}, \mathrm{Mg}, \mathrm{Pb}$ and $\mathrm{Zn}$, and the radionuclides ${ }^{210} \mathrm{~Pb}$ and ${ }^{210} \mathrm{Po}$ in the digestive gland of the squid Nototodarus gouldi. Mar Environ Res 13:55-68 Mollusca. Bull Jpn Soc scient Fish 44:325-329 
469 Warnau, M., Biondo, R., Temara, A., Bouquegneau, J.M., Jangoux, M., Dubois, P., 1998.

470 Distribution of heavy metals in the echinoid Paracentrotus lividus (Lmk) from the 471 Mediterranean Posidonia oceanica ecosystem: seasonal and geographical variations. J Sea 472 Res 39:267-280

473

474 Warnau, M., Teyssié, J-L., Fowler, S.W., 1996. Biokinetics of selected heavy metals and 475 radionuclides in the common Mediterranean echinoid Paracentrotus lividus: sea water and 476 food exposures. Mar Ecol Prog Ser 141:83-94

477

478 Whicker, F.W., Schultz, V., 1982. Radioecology: nuclear energy and the environment, Vol 2. 479 CRC Press, Boca Raton, FL

480

481 Wilkinson, L., 1988. Systat: the system for statistics. Systat Inc, Evanston, IL 482

483 Yamada, M., Aono, T., Hirano, S., 1999. ${ }^{239+240} \mathrm{Pu}$ and ${ }^{137} \mathrm{Cs}$ concentrations in fish, 484 cephalopods, crustaceans, shellfish, and algae collected around the Japanese coast in the early 485 1990s. Sci Tot Environ 239:131-142

486

487 Zar, J.H., 1996. Biostatistical analysis, $3^{\text {rd }}$ edn. Prentice-Hall, Upper Saddle River, NJ 
491 Fig. 1. Sepia officinalis. Whole-body loss kinetics of ${ }^{241} \mathrm{Am}$ and ${ }^{134} \mathrm{Cs}$ (\% of remaining 492 activity; mean $\pm \mathrm{SD})$ :

493 (A, B) juvenile cuttlefish previously exposed to spiked seawater for $36 \mathrm{~h}$ ( $\mathrm{n}=8$ from day 0 to 49420 and $n=4$ on day 29$)$;

495 (C, D) juvenile cuttlefish previously fed radiolabelled brine shrimp ( $\mathrm{n}=8$ from day 0 to 22 496 and $\mathrm{n}=5$ on day 29$)$;

497 (E, F) adult cuttlefish previously fed radiolabelled mussels ( $\mathrm{n}=18$ on day $0, \mathrm{n}=15$ from day 4981 to $18, \mathrm{n}=12$ from day 19 to 29 ).

499 Parameters of the best fitting equations are given in Table 3. 
500 Table 1. Sepia officinalis. Distribution (\%; mean \pm SD) of ${ }^{241} \mathrm{Am}$ and ${ }^{134} \mathrm{Cs}$ among three body 501 compartments of juvenile cuttlefish (1) after a 29-d exposure to spiked sediments, (2) after a 502 29-d depuration following a 36-h exposure to spiked seawater, and (3) after a 29-d depuration 503 following ingestion of spiked food (brine shrimp).

504

\begin{tabular}{|lcccc|}
\hline \multirow{2}{*}{ Exposure pathway } & \multirow{2}{*}{$\mathbf{N}$} & \multicolumn{3}{c|}{ Body compartment } \\
\cline { 3 - 5 } & & Digestive gland & Cuttlebone & Remaining tissues \\
\hline 1. Sediments (29-d exposure) & 3 & & & \\
$\quad{ }^{241} \mathrm{Am}$ & & $49 \pm 12$ & $12 \pm 3$ & $39 \pm 15$ \\
$\quad{ }^{134} \mathrm{Cs}$ & & $47 \pm 28$ & $17 \pm 4$ & $36 \pm 24$ \\
2. Seawater (29-d depuration) & 4 & & & \\
$\quad{ }^{241} \mathrm{Am}$ & & $27 \pm 13$ & $13 \pm 0$ & $61 \pm 13$ \\
$\quad{ }^{134} \mathrm{Cs}$ & 5 & $61 \pm 4$ & $5 \pm 0$ & $34 \pm 4$ \\
3. Feeding (29-d depuration) & & $59 \pm 23$ & $12 \pm 10$ & $29 \pm 16$ \\
$\quad{ }^{241} \mathrm{Am}$ & & $60 \pm 27$ & $22 \pm 21$ & $18 \pm 14$ \\
${ }^{134} \mathrm{Cs}$ & & &
\end{tabular}

505

506

507

508 
Table 2. Sepia officinalis. Parameters of the equations best fitting the whole-body loss kinetics of ${ }^{241}$ Am and ${ }^{134}$ Cs in cuttlefish previously exposed to the radionuclides via different pathways: (1) juveniles previously exposed for $36 \mathrm{~h}$ via seawater; (2) juveniles previously fed radiolabelled brine shrimp; (3) adults previously fed radiolabelled mussels.

$\mathrm{O}$ and T: one- and two-exponential loss equations, respectively; ASE: asymptotic standard error; $\mathrm{R}^{2}$ : determination coefficient; $\mathrm{p}$ : probability of the model adjustment.

\begin{tabular}{|c|c|c|c|c|c|c|c|c|c|}
\hline Pathway & Model & $A_{0 s}(\mathrm{ASE})$ & $\lambda s$ (ASE) & $\mathrm{T}_{\mathrm{b} 1 / 2 \mathrm{~s}}$ (days) & $A_{o l}(\mathrm{ASE})$ & $\lambda l$ (ASE) & $\mathrm{T}_{\mathrm{b} 1 / 21}$ (days) & $\mathrm{R}^{2}$ & $\mathrm{p}$ \\
\hline \multicolumn{10}{|c|}{ 1. Loss in juveniles after seawater exposure } \\
\hline${ }^{241} \mathrm{Am}$ & $\mathrm{O}$ & $87.7(2.8)$ & $0.048(0.005)$ & 14 & - & - & - & 0.96 & $<0.001$ \\
\hline${ }^{134} \mathrm{Cs}$ & $\mathrm{T}$ & $74.6(7.1)$ & $1.015(0.163)$ & 0.7 & $25.6(6.8)$ & $0.114(0.036)$ & 6.1 & 0.97 & $<0.001$ \\
\hline \multicolumn{10}{|c|}{ 2. Loss in juveniles after a single feeding on brine shrimp } \\
\hline${ }^{241} \mathrm{Am}$ & $\mathrm{T}$ & $39.6(10.5)$ & $1.282(0.654)$ & 0.5 & $60.3(10.1)$ & $0.137(0.029)$ & 5.1 & 0.95 & $<0.001$ \\
\hline${ }^{134} \mathrm{Cs}$ & $\mathrm{T}$ & $70.3(4.4)$ & $0.972(0.153)$ & 0.7 & $29.2(3.6)$ & $0.011(0.008)$ & 66 & 0.98 & $<0.001$ \\
\hline \multicolumn{10}{|c|}{ 3. Loss in adults after a single feeding on mussels } \\
\hline${ }^{241} \mathrm{Am}$ & $\mathrm{T}$ & $68.6(3.8)$ & $4.125(3.683)$ & 0.17 & $31.4(2.5)$ & $0.025(0.009)$ & 28 & 0.95 & $<0.001$ \\
\hline${ }^{134} \mathrm{Cs}$ & $\mathrm{T}$ & $77.6(4.4)$ & $1.310(0.197)$ & 0.53 & $22.5(3.7)$ & $0.045(0.019)$ & 16 & 0.95 & $<0.001$ \\
\hline
\end{tabular}


Table 3. Sepia officinalis. Concentration factors (CFs, mean), radionuclide activities $\left(\mathrm{Bq} \mathrm{g}^{-1}\right.$ wet wt; mean $\left.\pm \mathrm{SD}\right)$ and tissue distribution of radioactivity (\%; mean $\pm \mathrm{SD})$ in adult cuttlefish after $8 \mathrm{~h}$ of exposure via seawater $(\mathrm{n}=3)$ and after $6 \mathrm{~d}$ of depuration $(\mathrm{n}$ $=2)$.

\begin{tabular}{|c|c|c|c|c|c|c|c|c|c|c|c|}
\hline \multirow[t]{3}{*}{ Tissue } & \multirow[t]{3}{*}{$\%$ wet wt } & \multicolumn{5}{|c|}{${ }^{241} \mathrm{Am}$} & \multicolumn{5}{|c|}{${ }^{134} \mathrm{Cs}$} \\
\hline & & \multicolumn{3}{|c|}{ Accumulation $(8 \mathrm{~h})$} & \multicolumn{2}{|c|}{ Depuration $(6 \mathrm{~d})$} & \multicolumn{3}{|c|}{ Accumulation $(8 \mathrm{~h})$} & \multicolumn{2}{|c|}{ Depuration (6 d) } \\
\hline & & $\mathrm{CF}$ & Activity & $\%$ & Activity & $\%$ & $\mathrm{CF}$ & Activity & $\%$ & Activity & $\%$ \\
\hline $\begin{array}{l}\text { Branchial heart } \\
\text { appendages }\end{array}$ & $0.03 \pm 0.004$ & 16 & $103 \pm 66$ & $<1$ & 56 & $<1$ & 1 & $9 \pm 2$ & $<1$ & 1 & $<1$ \\
\hline Branchial hearts & $0.10 \pm 0.02$ & 42 & $264 \pm 85$ & $3 \pm 0$ & 203 & 3 & 2 & $13 \pm 1$ & $<1$ & 2 & $<1$ \\
\hline Gills & $2.3 \pm 0.3$ & 7 & $42 \pm 14$ & $10 \pm 2$ & 11 & 4 & 1 & $10 \pm 2$ & $4 \pm 0$ & 2 & 2 \\
\hline Digestive tract & $2.6 \pm 0.6$ & 2 & $15 \pm 5$ & $4 \pm 2$ & 4 & 2 & 1 & $10 \pm 1$ & $4 \pm 1$ & 1 & 1 \\
\hline Genital tract & $3.6 \pm 1.0$ & 1 & $9 \pm 5$ & $3 \pm 1$ & 2 & 1 & $<1$ & $4 \pm 1$ & $2 \pm 0$ & $<1$ & 4 \\
\hline Ink sack & $0.6 \pm 0.2$ & 2 & $12 \pm 1$ & $1 \pm 0$ & 7 & 1 & 1 & $7 \pm 3$ & $1 \pm 0$ & 2 & $<1$ \\
\hline Skin & $6.4 \pm 2.1$ & 1 & $6 \pm 4$ & $3 \pm 1$ & 3 & 2 & $<1$ & $4 \pm 2$ & $3 \pm 0$ & $<1$ & 4 \\
\hline Digestive gland & $4.3 \pm 1.2$ & 3 & $22 \pm 16$ & $10 \pm 2$ & 28 & 11 & $<1$ & $3 \pm 2$ & $2 \pm 1$ & 1 & 1 \\
\hline Kidney & $0.07 \pm 0.07$ & 2 & $13 \pm 5$ & $<1$ & 4 & $<1$ & 1 & $8 \pm 5$ & $<1$ & 1 & $<1$ \\
\hline Muscle & $35 \pm 2$ & 1 & $7 \pm 2$ & $26 \pm 4$ & 10 & 52 & 1 & $6 \pm 1$ & $36 \pm 3$ & 2 & 55 \\
\hline Head & $40 \pm 1$ & 1 & $9 \pm 3$ & $39 \pm 1$ & 4 & 23 & 1 & $7 \pm 2$ & $46 \pm 3$ & 1 & 32 \\
\hline Cuttlebone & $5.1 \pm 0.6$ & $<1$ & $2 \pm 1$ & $1 \pm 1$ & 2 & 1 & $<1$ & $1 \pm 1$ & $1 \pm 1$ & $<1$ & $<1$ \\
\hline Whole cephalopod & 100 & 2 & $10 \pm 3$ & 100 & 11 & 100 & 1 & $6 \pm 2$ & 100 & 3 & 100 \\
\hline
\end{tabular}


Table 4. Sepia officinalis. Radionuclide distribution among tissues (\%; mean $\pm \mathrm{SD}, \mathrm{n}=3$ ) of adult cuttlefish 1, 18, and $29 \mathrm{~d}$ after a single feeding on radiolabelled mussels.

\begin{tabular}{|c|c|c|c|c|c|c|}
\hline \multirow[t]{2}{*}{ Body compartments } & \multicolumn{2}{|c|}{$1 \mathrm{~d}$} & \multicolumn{2}{|c|}{$18 \mathrm{~d}$} & \multicolumn{2}{|c|}{$29 \mathrm{~d}$} \\
\hline & ${ }^{241} \mathrm{Am}$ & ${ }^{134} \mathrm{Cs}$ & ${ }^{241} \mathrm{Am}$ & ${ }^{134} \mathrm{Cs}$ & ${ }^{241} \mathrm{Am}$ & ${ }^{134} \mathrm{Cs}$ \\
\hline Branchial heart appendages & $<1$ & $6 \pm 9$ & $<1$ & $1 \pm 0$ & $<1$ & $2 \pm 0$ \\
\hline Branchial hearts & $3 \pm 0$ & $1 \pm 0$ & $<1$ & $2 \pm 1$ & $<1$ & $1 \pm 1$ \\
\hline Gills & $1 \pm 1$ & $3 \pm 2$ & $<1$ & $2 \pm 1$ & $<1$ & $2 \pm 1$ \\
\hline Digestive tract & $1 \pm 1$ & $3 \pm 1$ & $<1$ & $6 \pm 0$ & $<1$ & $9 \pm 1$ \\
\hline Genital tract & $<1$ & $2 \pm 1$ & $<1$ & $9 \pm 1$ & $<1$ & $10 \pm 6$ \\
\hline Ovary & $<1$ & $1 \pm 1$ & $<1$ & $3 \pm 1$ & $<1$ & $5 \pm 2$ \\
\hline Ink sack & $<1$ & $1 \pm 0$ & $<1$ & $1 \pm 0$ & $<1$ & $2 \pm 1$ \\
\hline Skin & $<1$ & $1 \pm 0$ & $<1$ & $2 \pm 1$ & $<1$ & $2 \pm 0$ \\
\hline Digestive gland & $89 \pm 7$ & $31 \pm 6$ & $97 \pm 1$ & $57 \pm 8$ & $98 \pm 0$ & $54 \pm 12$ \\
\hline Kidney & $<1$ & $1 \pm 0$ & $<1$ & $4 \pm 1$ & $<1$ & $2 \pm 0$ \\
\hline Muscle & $6 \pm 8$ & $22 \pm 3$ & $1 \pm 0$ & $6 \pm 5$ & $<1$ & $5 \pm 2$ \\
\hline Head & $2 \pm 1$ & $28 \pm 6$ & $1 \pm 0$ & $6 \pm 5$ & $1 \pm 0$ & $6 \pm 2$ \\
\hline Cuttlebone & $<1$ & $1 \pm 0$ & $<1$ & $2 \pm 1$ & $<1$ & $2 \pm 0$ \\
\hline
\end{tabular}


Juveniles exposed via sea water

Remaining activity (\%)

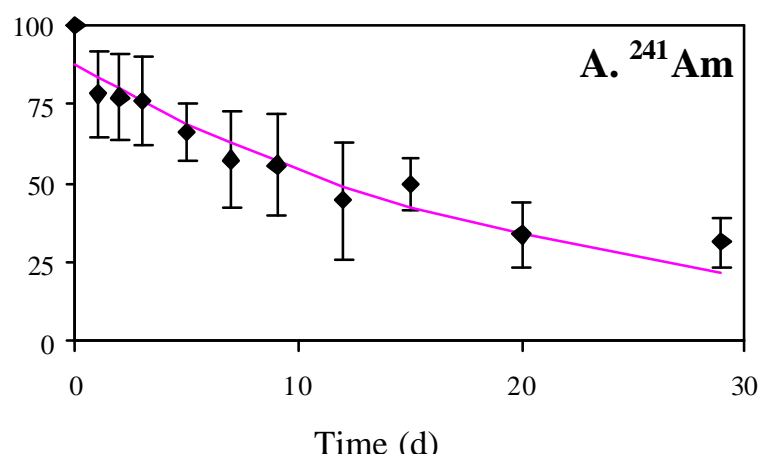

Remaining activity (\%)

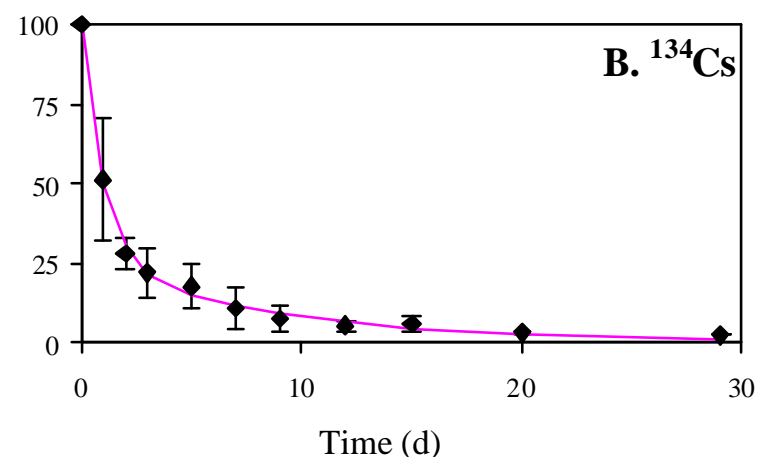

Juveniles fed brine shrimp

Remaining activity (\%)

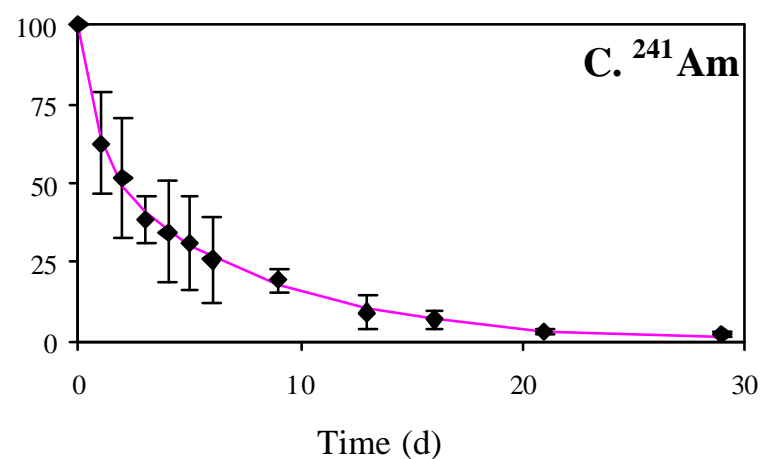

Remaining activity (\%)

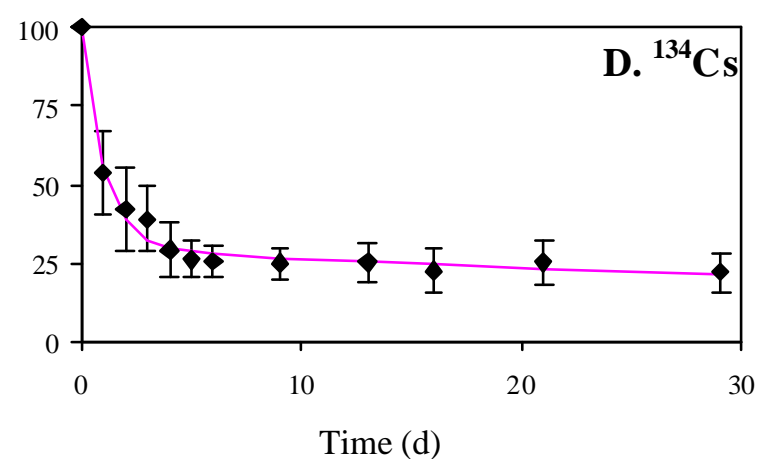

Adults fed mussels

Remaining activity (\%)

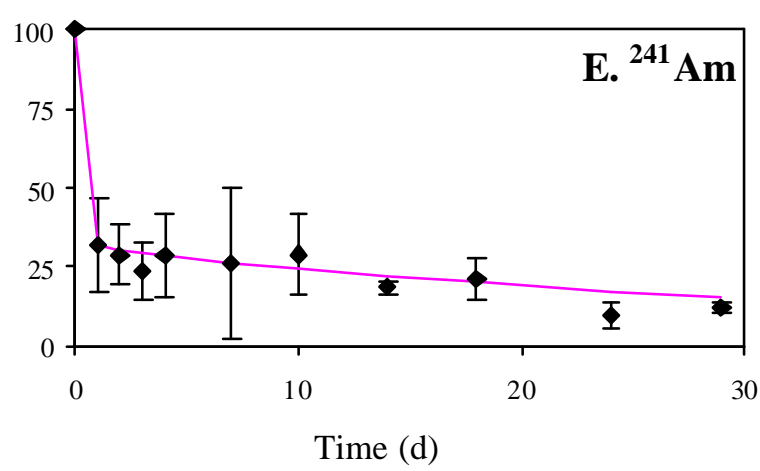

Remaining activity (\%)

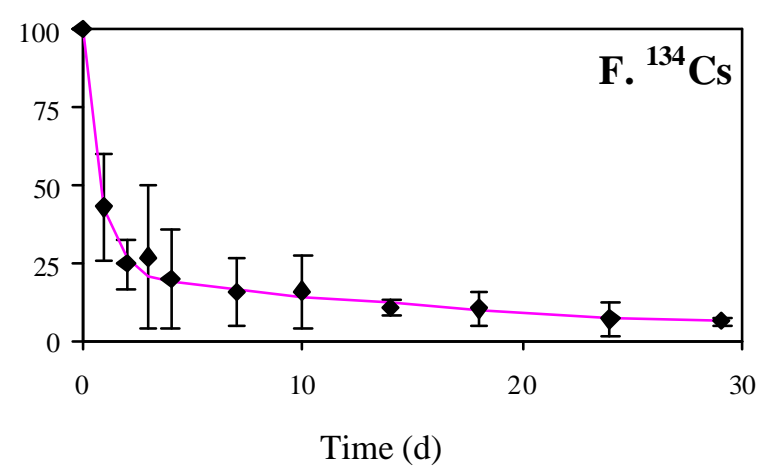

Fig. 1 